\title{
The SUMOylation machinery is dispensable for Tax-induced NF-kB activation
}

\author{
Sabrina Pène ${ }^{\dagger}$, Amandine Bonnet ${ }^{\dagger}$, Laetitia Waast, Laurence Bénit, Claudine Pique \\ From 16th International Conference on Human Retroviruses: HTLV and Related Viruses \\ Montreal, Canada. 26-30 June 2013
}

The HTLV-1 Tax protein is a good example of the diversity and functional importance of post-translational modifications. Indeed, Tax is phosphorylated, acetylated, conjugated to at least K48- and K63-linked poly-ubiquitin chains as well as to SUMO-1 and SUMO-2/3 molecules. In previous studies, we and others proposed that these modifications regulate both the intracellular distribution of Tax and its ability to activate the NF-kB pathway. In particular, Tax SUMOylation was associated to the formation of Tax nuclear bodies believed to represent transcriptionally active structures. However, our recent finding that a Tax mutant intrinsically weakly SUMOylated remains able to fully activate a NF-kB promoter challenged the importance of SUMOylation and/or nuclear body formation in the NF-kB activity of Tax. In this study, we further explored the role of Tax SUMOylation by targeting Ubc9, the unique E2 SUMO conjugating enzyme. We found that either a catalytically inactive form of Ubc9 (Ubc9-C93S) or Ubc9 siRNA totally blocks Tax conjugation to endogenous SUMO-1 or SUMO-2/3, showing that as expected, Tax SUMOylation is under the control of the catalytic activity of Ubc9. We next observed that this absence of Tax SUMOylation prevents neither the activation of the cytoplasmic IKK complex nor the activation of a NF-kB promoter. Finally, we also observed that surprisingly, the ability of Tax to form nuclear body was also not affected by overexpression of Ubc9-C93S. These data provide the direct demonstration that Tax SUMOylation and nuclear body formation are dispensable for Tax-induced NF-kB activation.

\footnotetext{
* Correspondence: claudine.pique@inserm.fr

+ Contributed equally

INSERM, U1016, Institut Cochin, CNRS, UMR8104, Université Paris Descartes, Sorbonne Paris Cité, Paris, France
}

(c) 2014 Pène et al; licensee BioMed Central Ltd. This is an Open Access article distributed under the terms of the Creative Commons Attribution License (http://creativecommons.org/licenses/by/2.0), which permits unrestricted use, distribution, and reproduction in any medium, provided the original work is properly cited. The Creative Commons Public Domain Dedication waiver (http:// creativecommons.org/publicdomain/zero/1.0/) applies to the data made available in this article, unless otherwise stated.
Submit your next manuscript to BioMed Central and take full advantage of:

- Convenient online submission

- Thorough peer review

- No space constraints or color figure charges

- Immediate publication on acceptance

- Inclusion in PubMed, CAS, Scopus and Google Scholar

- Research which is freely available for redistribution Submit your manuscript at
www.biomedcentral.com/submit C BioMed Central

\section{Biomed Central}

Published: 7 January 2014

Cite this article as: Pène et al:: The SUMOylation machinery is dispensable for Tax-induced NF-kB activation. Retrovirology 201411 (Suppl 1):O60. 